\title{
QUEEN'S
QNEIVERSITY
BELFAST
}

\section{Ireland's working-class literature: neglected themes, amphibian academics and the challenges ahead}

Pierse, M. (2020). Ireland's working-class literature: neglected themes, amphibian academics and the challenges ahead. Irish University Review, 50(1), 67-81. https://doi.org/10.3366/iur.2020.0435

\author{
Published in: \\ Irish University Review
}

\section{Document Version:}

Peer reviewed version

Queen's University Belfast - Research Portal:

Link to publication record in Queen's University Belfast Research Portal

\section{Publisher rights}

(C) 2020 Edinburgh University Press.

This work is made available online in accordance with the publisher's policies. Please refer to any applicable terms of use of the publisher.

\section{General rights}

Copyright for the publications made accessible via the Queen's University Belfast Research Portal is retained by the author(s) and / or other copyright owners and it is a condition of accessing these publications that users recognise and abide by the legal requirements associated with these rights.

Take down policy

The Research Portal is Queen's institutional repository that provides access to Queen's research output. Every effort has been made to ensure that content in the Research Portal does not infringe any person's rights, or applicable UK laws. If you discover content in the Research Portal that you believe breaches copyright or violates any law, please contact openaccess@qub.ac.uk. 


\section{Michael Pierse}

Ireland's working-class literature: neglected themes, amphibian academics and the challenges ahead*

Irish working-class history, culture, and literature are attracting increasing academic interest. With the publication of A History of Irish Working-Class Writing (2017), Declan Kiberd could write that its focus on 'an astonishing range of writing - from work-songs and political rhymes to poetry and government reports, from novels and plays to biographies by or about working people', would 'set many of the terms of cultural debate in the decade to come'. ${ }^{1}$ As he also noted, 'they could hardly be more timely': ${ }^{2}$ while Ireland's post-Crash society came to grips with the inequalities inherent in the injustices of the financial system and the policies of austerity, class sentiment seemed most manifest in, for example, the anti-water charges protests that gained popular support during the recession period. Rory Hearne noted a nascent, post-Celtic Tiger politicisation that had 'in particular mobilised lower income and working class areas'. ${ }^{3}$ Of course, this is a politicisation that is still resurgent in various, uneven forms across the globe, from Corbynism to Podemos to Alexandria Ocasio-Cortez, if in an age when the forces ranged against the left (many of them from among the working class) are also on the march. In this context, it was fitting that the Irish volume was published in parallel with books on British and American working-class literature, and that a chapter on the Irish context will feature alongside studies of South African, Swedish, American, Asian, and other working-class writers in a forthcoming follow-up volume to Magnus Nilsson and John Lennon's recent Working-Class Literature(s): Historical and International Perspectives (2017). ${ }^{4}$ Bringing such diverse perspectives on class and literature together was a feature of recent conferences too, of the international Working-Class Studies Association in Kent, and the European Labour History Network in Amsterdam (both September 2019). 'Class is a relationship, and not a thing', as E. P. Thompson famously declared, and investigating these relationships across space and time enriches our understanding of class globally and locally,

\footnotetext{
"This article is an extended and revised version of a piece, 'Back to class: Ireland's working-class literature', which was published in the Honest Ulsterman in June 2018, and is published here with thanks to magazine Editor, Dr Gregory McCartney.
} 
in all its complex and contradictory manifestations, providing an important resource for those grappling with class-related scholarly concerns. ${ }^{5}$ In Ireland, the experiences of the working class mapped out in history and literature have also empowered those struggling for social change. A sense of continuity with historical struggle was a key resource in recent years, as suggested, for example, by the compelling debates that emerged in Ireland's sometimes clumsy or contentious celebrations of the centenary of the Revolutionary Period. ${ }^{6}$ Some of those debates would focus on what James Connolly might have thought of the Ireland that subsequently emerged - his condemnations of capitalism jarring with the tax-haven Republic's inevitably thorny celebration of his legacy; as Timothy White and Denis Marnane noted of the opportunities for the left in the Decade of Centenaries,

at a time when the Left in Ireland appears to be getting some traction, the legacy of Connolly may at last be able to come in from the cold ... his leftist rhetoric that suggested a fundamental redress of economic inequalities is increasingly appealing among many who suffered from austerity policies. ${ }^{7}$

Connolly, as the subject of lore and song, has endured as a semi-mythic figure in Irish working-class life. And 'subliterary' forms such as song have indeed been integral to the formation of working-class culture, but how much effort has been made to unearth, preserve, curate, and indeed complicate our working-class heritage in Ireland, not least in terms of song, poetry, drama, fiction, and life writing? Scholars in recent years have presented in monographs, edited collections, anthologies - and, increasingly, digitised archives - from across British, American, European, and an increasing range of international contexts, a variety of resources for those who wish to consider how to carry the study on Irish workingclass writing onto new terrain. ${ }^{8}$ They consider class in relation to matters of form, material production, international comparative contexts, and diaspora experiences, among many other categories and themes, which suggest a range of potential directions in Irish Studies and class. Many of these scholars focus on British working-class literature and cultural studies, which have been to the fore of international scholarship in this area and provide a range of approaches that Irish Studies scholars can adopt or adapt, even as - as David Convery has noted - we must be careful not to simply map British experiences of class onto Irish ones. ${ }^{9}$

Folk song traditions indeed suggest potential affinities in relation to class and cultural histories across these islands. When The Full English, a digital archive of twelve manuscript collections of English folk songs, was launched in 2013 by the English Folk and Dance Song Society, playwright and screenwriter Lee Hall described it as 'the most exciting and 
significant thing to happen to British folk music in at least a generation.... To give everyone the keys to the archive of our common heritage will be an invaluable inspiration to generations of musicians and writers'. ${ }^{10}$ It was interesting that the scriptwriter of a classic film of the northern English working class, Billy Elliot (2000), had felt such affinities. Here was an archive - as Billy Bragg also recognised, along with fellow folk musicians and playwrights such as Hall and Neil Leyshon - which was rich with the history of the common folk, the peasant, the working class, and which, Bragg stressed, had relevance for contemporary working-class struggles. ${ }^{11}$ Such connections are not merely incidental, but often woven into the very fabric of this kind of creativity. Irish, British, and other folk song traditions share common traits; as John Moulden notes, for example, it is 'widely accepted that, in terms of the repertory of vernacular song, songs in English in Ireland, Scotland and England, and to a marked degree, in North America, Australia and New Zealand, are substantially related. ${ }^{12}$ Folk songs emerged over centuries as a form of popular entertainment that could provide, as well as diversion or levity, wellsprings of resilience and rebellion for the poor. ${ }^{13}$ They were easily learned and transcribed, handily stored (often hidden from authorities) and frequently modified, if need be, to chime with the particularities of place and time. In A History of Irish Working-Class Writing, Moulden draws our attention to the ways in which, 'from the poorest in society, the Irish working class created, contributed to, transformed and consumed the verbal art that impinged upon them in oral or cheap printed or, occasionally, more substantial form', creating, performing and distributing a folk culture that would transform through space and time. ${ }^{14}$ These songs were truly of a 'folk' experience lamenting injustices or recounting common concerns, such as in 'The Cottager's Complaint', or eulogising exceptional individuals, as in 'Hannah Healy the Pride of Howth', or 'Biddy Mulligan the Pride of the Coombe'. ${ }^{15}$ Notwithstanding commendable work such as Moulden's, and that of the Irish Traditional Music Archive, for example, we could do more to trace and disseminate the ways in which this music and song, over centuries, has been part of a tradition that has often mutated and migrated but continually expressed values that can be theorised in terms of class as well as postcolonial politics. In a broader sense, we could also do more to consider the scope and substance of the cultural and intellectual life of the Irish working class at home and abroad. Studies such as Christopher Hilliard's To Exercise Our Talents: The Democratisation of Writing in Britain (2006) and Jonathan Rose's The Intellectual Life of the British Working Classes (2010) suggest possibilities for similar work in Ireland. ${ }^{16}$ 
The Irish Labour History Society Museum in Dublin and the recently opened James Connolly Centre in Belfast have made strides in this regard, but in the academy, despite the development, over many decades, of a sophisticated and diverse range of critical approaches in Irish Studies, there is still a relative lack of discussion around how class has shaped and shapes the contours of Irish social, political, and cultural life. Class is indisputably at the heart of Irish society, north and south, its operations, apparatuses, privileges, and anxieties, as scholars such as Liam Cullinane, Colin Coulter, Graham McFarlane, Marilyn Silverman, David Convery, and Christopher J.V. Loughlin have illustrated; it is central to its academies and its intellectual cultures, as others, like Fergal Finnegan, Barbara Merill, and Ciarán Burke have recently shown. ${ }^{17}$ And class politics are abundant in literature and the arts. In terms of cultural production, A History pointed to the extent of Irish working-class literature that will provide fruitful material for scholars grappling with matters of culture and class in the time to come. Nils Beese's recent Writing Slums: Dublin, Dirt and Literature (2018) suggests potential in the study of literature and working-class space by 'shed[ding] light on the development of slum literature and what one might class Modernist slum aesthetics' ${ }^{18}$ Susan Cannon Harris's recent monograph, Irish Drama and the Other Revolutions: Playwrights, Sexual Politics and the International Left, $1892-1964$ (2017), also conveys, for example, the potential in relation to class and intersectional politics in twentieth-century drama, paving a path, as she puts it, "to restore to visibility a tradition of left theatre which originated at the intersection between socialist politics and sexual politics'. ${ }^{19}$ Cannon Harris looks at New Women and queer socialism in the 1890s, syndicalism and masculinity in the Abbey of the 1910s, and O'Casey's less-explored relationship with post-realism and the Soviet Union, for example. Her book supports the 'pursuit of a truly internationalist understanding' of Irish literature, and that internationalist focus is further enriched by recent scholarship on the Irish emigrant in literature, in which Liam Harte, Tony Murray, Peter Kuch, Margaret Hallissy, John Lutz have been leading the charge, and in which working-class experience is such a strong feature. ${ }^{20}$

Another topic for further investigation is class in the Irish arts infrastructure: we have little research in Ireland on the quantifiably material dynamics behind our cultural and arts institutions and their qualitative impact, though Cultural Policy Observatory Ireland, established in 2015, has been keen to expand the research base in this regard. ${ }^{21}$ Britain has, in recent decades, produced significant studies (for example The Warwick Commission Report, which notionally covers the 'UK', but lamentably does not include the northern Irish context) 
that have pointed to the extent and historical development of class (and race and gender) inequalities and challenges in the arts. ${ }^{22}$ In Ireland of late, welcome attention was drawn to gender inequalities in theatre: the \#WakingtheFeminists movement revealed, when it emerged in 2015, a staggering bias toward male artists in the Abbey Theatre's 'Waking the Nation' programme. The protests this movement inspired have prompted significant attitudinal and substantive programming changes. ${ }^{23}$ But where were working-class women in all of this? As Maggie Armstrong observed, at least one feminist protester felt ill-at-ease during the campaign:

It was pretty historic. Feminism, so often a stuffy, if not totally threatening, term, was suddenly the New Order. But it was another f-word that had people shifting in their seats, when a silver-haired woman spoke from the crowd. 'A big fair $\mathrm{f}^{* * *} \mathrm{~s}$ to everyone,' said Cathleen O'Neill, working-class activist. She said she felt proud today, but needed to raise another matter - class. Theatre for the working-class is 'relegated to community arts,' she said. 'Don't forget us, sisters,' she implored the well-heeled theatre-makers on the stage.... Cathleen described how she left the Abbey 'on fire, empowered by it'. But also, 'seething'.... She had gone along to support the women's struggle. But she did not feel as supported by them. She felt that in speaking out about their oppression as women, they had divorced their cause from another, more life-threatening form of oppression - poverty... 'Theatre is seen as too expensive, exclusive, not for us,' said Cathleen. ${ }^{24}$

There is little data, qualitative or quantitative, produced in this regard. Sandy Fitzgerald's 2004 reader on community arts in Ireland, An Outburst of Frankness, grappled, for example, with some of the issues relating to class in the Irish arts scene, such as funding, access and participation, from historical, practitioner and policy perspectives, though it was 'not an academic book' and was written in an environment where data on class and the arts was relatively scarce in comparison with the British context. ${ }^{25}$ It did, nonetheless, point up some important issues emerging in late twentieth-century Ireland in regard to class and culture: the 1994 study The Public and the Arts, cited in Paula Clancy's chapter, which showed that, over the previous thirteen years,

in relation to certain types of events [in the Republic], and particularly those that form the focus of the publicly funded arts, there was found to be a widening of the class differential, particularly in relation to the semi-skilled/unskilled working class. These 
events included plays, performances of classical music and exhibitions of paintings and sculptures - art forms that traditionally attracted a middle-class audience. ${ }^{26}$

There were widening gaps too in terms of the purchase of cultural products (including novels, poetry, and music records/tapes), but Clancy points in her chapter to the need for further data on class and region, and this is still very much the case in 2019 , leaving many pressing questions unanswered. What are the class dynamics at the Abbey, or in organisations such as the Arts Council, Culture Ireland, Aosdána, or the Dublin Fringe Festival? Who gets funded and supported? Who gets what jobs, and where (in terms of class, ethnicity, gender, and region) do they come from? Who is entertained? The sparseness of thoroughgoing studies on these matters would suggest we have a long way to go in acknowledging the role of class in cultural (and social) production in Ireland.

\section{'Class is always in some sense present'}

Working-class people don't often get to see themselves in Irish theatres and not enough in television drama or fiction, and when they do, the depiction is often negative. Recently, fiction writers E. R. Murray, Dave Lordan, and Sheena Wilkinson discussed the lack of 'champions for children from poorer backgrounds' in young-adult fiction, for example. ${ }^{27}$ According to Murray: 'When we speak about diversity within publishing, we're frequently referring to gender, sexuality, race, language and disabilities. All of these badly need to be represented ... but I wonder, where are the champions for the lower socio-economic backgrounds?' ${ }^{28}$ Wilkinson's inclusion of working-class characters in her young-adult novels relates to alienating personal experiences: 'I grew up with the only available Belfast narratives focusing on religion and cultural identity, when what I saw around me suggested that the divisions were at least as much to do with social class' ${ }^{29}$ Lordan, from Cork, furthermore points to the difficulty of becoming a working-class writer: 'Class is a huge factor. Many of the successful authors I know around my age and younger receive huge backing from well-off parents over the decade or so it takes to get established.' ${ }^{30}$

Jeremy Hawthorne would note that, "for some people, "working-class novel" is a contradiction in terms '. ${ }^{31}$ He identified the material barriers to writing for the less well-off: 'such things as literacy, leisure time for reading, publishers sympathetic to their values (not to mention teachers and lecturers), have all been much more easily obtained by upper- and 
middle-class people than by members of the working class. ${ }^{32}$ Despite the Arts Council and Combat Poverty's joint report, 'Access and Participation in the Arts' (1997), pointing some decades ago to these inequalities in Ireland, little has been done since in terms of research that might support policy change. ${ }^{33}$ As a more recent report (2014) highlighted (quoting here Peter Lunn and Elish Kelly):

While there remains a lack of data about the resources dedicated to cultural inclusion, there is evidence to indicate that people from disadvantaged socio-economic backgrounds with lower levels of educational attainment display equal levels of interest in the arts but are 'many times less likely' to participate in cultural events than their better-off counterparts.... Despite an Oireachtas (Parliamentary) Committee hearing in 2012 to consider how best to support and ensure the participation of disadvantaged groups in cultural life, no recommendations or actions have been issued. $^{34}$

John Kirk begins his study of the British working class in film, literature, and television by observing how 'class is always in some sense present: whether in our refusal to accept it, our inclination to acknowledge it or insist on it or, as in some cases, our being privileged enough not to have noticed it. ${ }^{35}$ It is often when class is least spoken about, or when it is most comfortably acknowledged to be old-fashioned or irrelevant, that it is most pressing in our social machinery and everyday lives, not least in cultural terms. In Ireland, there is nothing of the detailed abundance of work by Mike Savage, in Britain, or Pierre Bourdieu, in France, in the sociological study of class - a lamentable absence that leaves cognate research impoverished. ${ }^{36}$

The general theorisation of social class in Ireland, north and south, is relatively poor, which in turn has hampered connectivity between disciplines in relation to how class manifests itself in things like publishing or arts participation. ${ }^{37}$ Some work, by scholars like Marilyn Silverman, Chris Eipper, and, more recently, Fergal Finnegan, for example, has shown how the shame, anger, deprivation and defiant pride that underpin class relations elsewhere are manifest in Irish life. ${ }^{38}$ The work of Helena Sheehan on Irish television drama pointed to the extent of the national broadcaster's role in reproducing class inequalities. ${ }^{39}$ But Sheehan's trailblazing work has yet to be followed by such significant interrogations of class in RTÉ's more recent decades: what are the unthinking class biases in Love/Hate or Fair City, for example? As Tom Maguire has recently noted of RTÉ comedy, 
the station has repeatedly presented material the humour of which relies on caricatures of the poor. As an example, Andrew Quirke created two characters, Damo and Ivor initially within a sketch show, The Republic of Telly in 2011. In 2013 a stand-alone television show debuted on RTÉ Two. As David Toms comments, the show 'derives its apparent humour from the contrasting of two rather lazy stereotypes of Dublin, one of a northside "skanger" called Damo, and the other of an equally lazy Ross O'Carroll-Kelly imitation called Ivor.' The use of "skanger" or "knacker" in Ireland parallels the use of "chav" within British culture (Jones) to vilify the poor. Quirke's characterisation of Damo exploits the working-class stereotype: stupid, lazy, drunken, foul-mouthed and aggressive. It is notable that Quirke as creator and performer is the son and heir of a millionaire businessman... The generation of these stereotypes in the media has also found an echo in the wider culture. ${ }^{40}$

Intersectionality is also at issue. While in An Irish Working Class (2001) Silverman addressed the everyday injuries of class in much more intimate and interpersonal contexts in small-town Ireland, it remains to be asked how have those experiences changed and intersected with issues of race, for example, in recent decades, as newcomers join the Irish working class in unprecedented numbers? And what of those other intersectional experiences documented by scholars like Beverley Skeggs in Britain - the specific manifestations of class for women, or LGBTQ people and BME groups in Ireland? At the intersection of feminism and class-analysis, Nicola Wilson, in her study of British working-class domestic space in fiction, recently noted the continuing merit in Ken Worpole's observation of more than three decades ago that 'the two major traumas that dominate the working class life are, not the strike, not the factory accident, but early and unwanted pregnancy and hasty marriage, or the back-street abortion'; ${ }^{41}$ such experiences in Ireland are captured in poetry, stories, and plays, by Paula Meehan, Christina Reid, and Roddy Doyle, among others. Recent work by Heather Laird and Tom Maguire is important in opening this matter to further scholarly inquiry. As Maguire suggests, in his exploration of aspects of violence and working-class women on the Irish stage, 'naturalistic dramatic representation of the home as a domestic sphere for poor women may confound nationalist discourses of the country as home, yet may fail to resist the systemic violence of the state against its most precarious citizens. ${ }^{42}$ His focus on popular cultural demonisations of the poor and theatrical responses to them is welcome and chimes with Laird's commentary on representations of motherhood in Irish fiction, both essays, as Laird puts it of her own, laying 'the foundations for much-needed further scholarly work on 
the representation of working-class Irish women'. ${ }^{43}$ Playwrights and novelists such as Doyle, Donal O'Kelly, Ken Harmon, Brian Campbell, Dermot Bolger, Vincent Higgins, Jim O’Hanlon, Bisi Adigun, Charlie O’Neill, Mirjana Rendulic, and Ursula Rani Sarma have been answering questions about immigrant experiences of class in recent years, in often contradictory ways, but few scholars have pointed to this intersectionality. ${ }^{44}$ Traveller experiences of class, such as that depicted in Rosaleen McDonagh's Rings (2012), are also less considered. Developing interdisciplinary perspectives is difficult when the disciplines are only beginning to communicate on such matters. This was precisely the challenge impelling the foundation of the Irish Centre for the Histories of Labour and Class in 2013, at the Moore Institute in NUI Galway - a commendable forward step in encouraging conversations between historians, sociologists, cultural and literary studies scholars and others in developing broader perspectives on class.

Class, culture, and education

Ruth Sherry observed some thirty years ago that 'the concept of Irish working-class writing is not a well-established one. ${ }^{45}$ The same could be said today in general terms, though at the least, through recent and ongoing $\mathrm{PhD}$ studies and the publication of scholarly work in the field, it is evident that the language of class politics in Irish literary studies scholarship is here to stay. That Sherry could identify some of the major prose writers of the Irish working class prior to the publication of her article, 'The Irish Working Class in Fiction', in 1985, suggests, however, that the relative neglect of working-class writing since has been inexcusable. Despite book-length studies on Brendan Behan, Seán O'Casey, Sam Thompson, Christy Brown, Stewart Parker, Roddy Doyle and others, research that links such writers together as 'working class' was until recently quite rare and is still in its infancy. ${ }^{46}$ Some of this has of course to do with the very structure of our education system; scholarly attention to marginalised and disadvantaged communities is often initiated by people who emerge from those communities into the academy, but what if few outsiders get through? Does the academy buttress the inequality in how cultural (and social, and other forms of) capital are distributed in Irish society, north and south, through the education system?

In a recent comparative study of the experiences of working-class English and Irish university students, Finnegan and Barbara Merrill found promising strides forward through 'widening participation' measures in higher education, but also observed, more depressingly, the endurance of feelings of alienation amongst working-class higher-education students. A 
high proportion had, at university, experienced 'a feeling of dislocation, or at least a sense of social distance, from the dominant culture in universities', one of the Irish students describing university as 'a foreign country'. ${ }^{47}$ Those attending elite institutions were particularly alienated:

in some cases interviewees discussed going through the difficult and painstaking process of cultural adaptation ... [and] [t] hese accounts of fitting or not fitting in at university were often discussed as something which was felt as embodied and as deeply emotional by the students. ${ }^{48}$

Secondary school can be similarly alienating; Roddy Doyle's Paula Spencer learns in school 'that I wasn't good at all', and that her teachers 'all the same, cunts. Cunts. I hated them. ${ }^{49}$ Such sentiments are frequent in Irish working-class writing. ${ }^{50}$

While questions of access have come to the fore in universities on these islands, how many have asked how the class of people working and studying in universities influences the class of subjects researched and taught, and how they are taught? bell hooks once argued, in a US context, that "nowhere is there a more intense silence about the reality of class differences than in educational settings'. ${ }^{51}$ There has been some quantitative and mixed-method research on the underrepresentation of the working class in Irish higher education in recent decades, but only 'a small number of qualitative studies have explored the potential barriers to HE' in the Republic. ${ }^{52}$ Research on teachers has confirmed 'the significant under-representation of, inter alia, certain lower socio-economic groups' in the Irish teaching profession, and while I am not aware of similar research on academics, it is not unreasonable to suspect that this more prestigious tier of the education system is just as, if not more, elitist. ${ }^{53}$ How does this skewing distort the study and teaching of Irish life? How does it impact curricula and matters of epistemology? If, as Keane, Heinz, and Lynch note, for example, 'research has found that working-class teachers positively impact working-class pupils', what is the impact of a system that produces and embeds classism? ${ }^{54}$ This is to say, as Skeggs has, that 'the ability to claim and promote an identity is often based on access to sites of representation such as higher education and the media; the working class (women and men, black and white) have always had restricted access to where these claims are most frequently made'. ${ }^{55}$ In Ireland, this is also demonstrably the case, but not a lot of scholars seem to be making that case.

Thus, to adapt a turn of phrase of Terry Eagleton's, there is no need to bring class into literature; it has been there right from the start. In Irish literature, we are beginning to see 
welcome attention, from a range of thinkers, to the ways in which the canonical has been shaped by class, and the ways in which class has emerged in cultural production - whether in the form of political poems in the pages of the Irish Worker, the ground-breaking and controversial novels and TV series of Roddy Doyle, or the mesmeric rap-poetry of Emmet Kirwan. The recent publication of The Children of the Nation: An Anthology of Working People's Poetry from Contemporary Ireland (November 2019), edited by Jenny Farrell, and author Paul McVeigh's announcement of his forthcoming collection, The 32: An Anthology of Irish Working-Class Voices (scheduled for publication in 2020) are very promising developments too. McVeigh explained recently, of the impetus behind his book, which seeks to follow on the success of Kit de Waal's British collection, Common People: An Anthology of Working-Class Writers (2019), 'too often, working class writers find that the hurdles they have to leap are higher and harder to cross than for writers from more affluent backgrounds.... The 32 will see writers who have made that leap reach back to give a helping hand to those coming up behind. ${ }^{56}$ Fittingly, some profits from the publication will be set aside for development workshops with fledgling working-class authors. There is undoubted evidence here of a recent impetus in the exploration and encouragement of working-class cultural production in Ireland. In the academy, this work will hopefully lead to new ways of conceptualising Irish cultural history and indeed of coming to grips with the dynamics of Irish society now and into the future. Often it is being conducted by working-class 'amphibians' - as Michelle Tokarczyk terms them, in her commentary on the study of American working-class writers - those critics from working-class backgrounds who, she argues, 'act as a bridge between working-class and academic sensibilities' ${ }^{57}$ Certainly, in a context of continued austerity, and with growing student expenses at HE in Ireland north and south, these 'bridges' are needed to challenge the ways in which the working class is written, or written about. 
${ }^{1}$ Declan Kiberd, foreword to A History of Irish Working-Class Writing, ed. by Michael Pierse (Cambridge: Cambridge University Press, 2017), pp.xiii-xviii (p.xviii).

${ }^{2}$ Kiberd, p.xviii.

${ }^{3}$ Rory Hearne, 'The Irish water war, austerity and the "Risen people": An analysis of participant opinions, social and political impacts and transformative potential of the Irish anti water-charges movement', Maynooth University. Published online:

https://www.maynoothuniversity.ie/sites/default/files/assets/document/TheIrishWaterwar_0.pdf. Accessed 1 September 2019.

${ }^{4}$ Michael Pierse, 'A brief overview of Irish working-class writing', in Literature(s): Historical and International Perspectives: Volume II, ed. by John Lennon and Magnus Nillson (forthcoming PUBLISHER? 2020).

${ }^{5}$ E.P. Thompson, The Making of the English Working Class (London: Penguin, 1980), p.10.

${ }^{6}$ See Johanne Devlin Trew and Michael Pierse (ed.) Rethinking the Irish Diaspora - After the Gathering (Basingstoke: Palgrave, 2018), pp. 251-252. See also, for an example of the controversies that emerged, Anne Dolan, 'Commemorating 1916: How much does the integrity of the past count? "In its own peculiar way, Ireland Inspires quite eloquently expresses the gap between history and commemoration"', Irish Times, 2 January 2018.

${ }^{7}$ Timothy J. White \& Denis Marnane, 'The Politics of Remembrance: Commemorating 1916', Irish Political Studies 31.1 (2016), 29-43 (p.33).

${ }^{8}$ See for example Janet Zandy, Calling Home: An Anthology of Working-Class Women's Writing (New Jersey: Rutgers University Press, 1990); What we Hold in Common: An Introduction to Working-Class Studies, ed. by Janet Zandy (New York: The Feminist Press at the University of New York, 2001); American Working-Class Literature: An Anthology, ed. by Zandy and Nicholas Coles (New York: Oxford University Press, 2007);New Working-Class Studies, ed. by John Russo and Sherry Lee Linkon (Ithaca: Cornell University Press, 2005); Critical Approaches to American Working-Class Literature, ed. by Michelle M. Tokarczyk (New York and London: Routledge, 2011); Paul Lauter, 'Working-Class Women's Literature: An Introduction to Study', Radical Teacher 15 (1980), 16-26; Working-Class Literatures: Historical and International Perspectives, ed. by Magnus Nilsson and John Lennon (Stockholm: Stockholm University Press, 2017).

${ }^{9}$ David Convery, 'Writing and Theorising the Irish Working Class', in A History of Irish Working-Class Writing, pp.37-56.

${ }^{10}$ Katie Bond, 'Folk music archive gains Swindon link', Swindon Advertiser, 4 July 2013, https://www.swindonadvertiser.co.uk/news/10524613.folk-music-archive-gains-swindon-link/ Accessed 16 May 2019.

${ }^{11}$ Taken from commentary by Bragg on the radio documentary 'Digital Folk: John Kirkpatrick discovers how the digitised archive of England's folk songs is used by Billy Bragg and Lee Hall', broadcast on BBC Radio 4 in 2013. See description online: https://www.bbc.co.uk/programmes/b0383vxr. Accessed 5 June 2019.

${ }^{12}$ John Moulden, 'Sub-literatures?: Folk Song, Memory and Ireland's Working Poor', in A History of Irish Working-Class Writing, pp.102-121 (p. 111).

${ }^{13}$ See Georges Denis Zimmermann, Songs of Irish Rebellion - Irish Political Street Ballads and Rebel Songs (Dublin: Four Courts Press, 2002), p.2.

${ }^{14}$ Moulden, 'Sub-literatures?: Folk Song, Memory and Ireland's Working Poor', p.102.

${ }^{15}$ See $A$ History of Irish Working-Class Writing, pp.109-110.

${ }^{16}$ Christopher Hilliard, To Exercise Our Talents: The Democratization of Writing in Britain (London: Harvard University Press, 2006); Jonathan Rose, The Intellectual Life of the British Working Classes (London: Yale University Press, 2001).

${ }^{17}$ For a summary of the extant research see David Convery, 'Writing and Theorising the Irish Working Class', in Pierse (2017), pp.37-56. See also Liam Cullinane, “'As If You Were Something Under Their Shoe”: Class, Gender and Status among Cork Textile Workers, 1930-70', in Locked Out: A Century of Irish Working-Class Life, ed. by David Convery (Dublin: Irish Academic Press, 2013), pp.175-191; Colin Coulter, 'The Absence of Class Politics in Northern Ireland', Capital \& Class 22 (1999), 77-100; Graham McFarlane, 'Dimensions of Protestantism: The Working of Protestant Identity in a Northern Irish Village', in Ireland from Below: Social Change and Local Communities, ed. by Chris Curtin and Thomas M. Wilson (Galway: Officina Typographica/Galway University Press, n.d. [1990?]), pp.23-45; Marilyn Silverman, An Irish Working Class: Explorations in Political Economy and Hegemony, 1800-1950 (Toronto: Toronto University Press, 2001); Christopher J. V. Loughlin, 'Representing Labour: Notes towards a Political and Cultural Economy of Irish Working-Class Experience', in Pierse (2017), pp.57-71. With regard to educational matters, see Fergal Finnegan and Barbara Merrill's recent essay “'We're as good as anybody else': a comparative study of working-class university student experiences in England and Ireland', British Journal of Sociology in Education (5 October 
2015). http://www.tandfonline.com/doi/abs/10.1080/01425692.2015.1081054.Accessed 12 May 2016. And Ciaran Burke, Culture, Capital and Graduate Futures: Degrees of Class (London: Routledge, 2015).

${ }^{18}$ Nils Beese, Writing Slums: Dublin, Dirt and Literature (Oxford: Peter Lang, 2018), p.261.

${ }_{19}$ Susan Cannon Harris, Irish Drama and the Other Revolutions: Playwrights, Sexual Politics and the International Left, 1892-1964 (Edinburgh: Edinburgh University Press, 2017), p.238.

${ }^{20}$ Cannon Harris, p.240.; Liam Harte, The Literature of the Irish in Britain: Autobiography and memoir, 17252001 (Basingstoke, Palgrave Macmillan, 2009); Tony Murray, London Irish Fictions: Narrative, Diaspora and Identity (Liverpool: Liverpool University Press, 2012); Peter Kuch, 'Irish Working-Class Writing in Australasia, 1860-1960: Contrasts and Comparisons', in Pierse (2017), pp.226-242; Margaret Hallissy and John Lutz, 'The View from Below: Solidarity and Struggle in Irish-American Working-Class Literature', in Pierse (2017), pp.209-225.

${ }^{21}$ See the organisation's website here: https://culturalpolicyireland.org. Accessed 10 September 2019.

${ }^{22}$ Jonothan Neelands, Eleonora Belfiore, Catriona Firth, Natalie Hart, Liese Perrin, Susan Brock, Dominic Holdaway, Jane Woddis, Enriching Britain: Culture, Creativity and Growth: The 2015 Report by the Warwick Commission on the Future of Cultural Value (Coventry: University of Warwick, 2015). See also Dave O'Brien, Orian Brook, and Mark Taylor, Panic! Social Class, Taste and Inequalities in the Creative Industries (Report: 2018); Robert Hewison, Cultural Capital: The Rise and Fall of Creative Britain (London: Verso, 2014).

${ }^{23}$ See Mary Moynihan, 'Analysis: in three years, the Waking the Feminists grassroots movement has had a seismic impact on Irish theatre and culture', 22 November 2018, RTÉ Brainstorm

https://www.rte.ie/brainstorm/2018/1122/1012586-how-waking-the-feminists-set-an-equality-agenda-for-irishtheatre/. Accessed 22 August 2019.

${ }^{24}$ Maggie Armstrong, 'Stage: Is Irish theatre now too elitist and middle class', Irish Independent, 22 November 2015, https://www.independent.ie/entertainment/theatre-arts/stage-is-irish-theatre-now-too-elitist-and-middleclass-34217551.html.Accessed 5 August 2019.

${ }^{25}$ Sandy Fitzgerald, An Outburst of Frankness: Community Arts in Ireland - A Reader (Dublin: TASC at New Island, 2004). Referenced quote is from the back-cover blurb.

${ }^{26}$ Paula Clancy, 'Rhetoric and reality: a review of the position of community arts in state cultural policy in the Irish republic', in Fitzgerald, An Outburst of Frankness: Community Arts in Ireland - A Reader, pp. 83-114 (p. 103).

${ }^{27}$ E.R. Murray, 'YA fiction - is it a class act?', The Irish Times, 27 July 2016,

http://www.irishtimes.com/culture/books/ya-fiction-is-it-a-class-act-1.2736395_Accessed 10 June 2019.

${ }^{28}$ Murray, 'YA fiction'.

${ }^{29}$ Murray, 'YA fiction'.

${ }^{30}$ Murray, 'YA fiction'.

${ }^{31}$ Jeremy Hawthorn, preface to The British Working-Class Novel in the Twentieth Century (London: Edward Arnold, 1984), p.vii.

${ }^{32}$ Hawthorn, p.viii.

33 Jeanne Moore, Poverty: Access and Participation in the Arts (Dublin: Combat Poverty Agency and The Arts Council, 1997). See also, however, examples such as: Donal O'Donoghue 'Higher education in art and design: Access participation and opportunity', Irish Educational Studies 21.3 (2002), 111-129; Jeanne Moore 'Poverty and access to the arts: Inequalities in arts attendance', Cultural Trends 8.31 (1998), 53-73; Fitzgerald, An Outburst of Frankness: Community Arts in Ireland - A Reader; P. Lunn and E. Kelly, In the Frame or Out of the Picture? A statistical analysis of public involvement in the arts (Dublin: National Economic and Social Forum, 2009); ESRI, Accounting for taste: an examination of socio economic gradients in attendance at arts events, ESRI Working paper 283 (Dublin: Economic and Social Research Institute, 2009); N. Hunt, G. Granville, C. Maguire, and F. Whelan, 'Academy and community: the experience of a college programme in socially-engaged practice', International Journal of Education through Art 8.3 (2012), 271-285. An Arts Council strategic review in 2014 also suggested an awareness of its own failures in this regard, noting arts practice in Ireland's disconnect with 'significant cohorts of the population' and 'almost exclusive emphasis on the production/consumption model of the arts', with 'little emphasis on engagement and participation as a fundamental and valued aspect of the arts in Irish society'. See Arts Council, Inspiring Prospects: Arts Council Strategic Review 2014 - Report of the Steering Group (Dublin: Arts Council, 2014), pp.4-5.

${ }^{34}$ FLAC, 'Our Voice, Our Rights: a parallel report in response to Ireland's Third Report under the International Covenant on Economic, Social and Cultural Rights' (Dublin: FLAC, 2014), pp.98-99.

${ }^{35}$ John Kirk, The British Working Class in the Twentieth Century: Film, Literature and Television (Cardiff: University of Wales Press, 2009), p.1.

${ }^{36}$ See Mike Savage, Social Class in the $21^{\text {st }}$ Century (London: Pelican, 2015); Pierre Bourdieu, Distinction - A Social Critique of the Judgement of Taste, trans. by Richard Nice (London: Routledge, 1998).

${ }^{37}$ See David Convery, 'Writing and Theorising the Irish Working Class', in Pierse (2017), pp.37-56, esp. pp.5056. 
${ }^{38}$ See Silverman reference above; Chris Eipper The Ruling Trinity: A Community Study of Church, State and Business in Ireland (Aldershot: Gower Publishing, 1986) and Hostage to Fortune: Bantry Bay and the Encounter with Gulf Oil (St. John's, Newfoundland: Institute of Social and Economic Research, Memorial University of Newfoundland, 1989). Fergal Finnegan, Barbara Merrill, and Camilla Thunborg (ed.), Student Voices on Inequalities in European Higher Education: Challenges for theory, policy and practice in a time of change (London: Routledge, 2014).

${ }^{39}$ Helena Sheehan, Irish Television Drama: A Society and its Stories (Dublin: RTÉ, 1987; re-published in a revised edition on CD-ROM, 2004) and The Continuing Story of Irish Television Drama: Tracking the Tiger (Dublin: Four Courts Press, 2004).

${ }^{40}$ Tom Maguire, 'The State We're in: Violence and Working-Class Women on and off the Contemporary Irish Stage', Journal of Contemporary Drama in English 6.1 (2018), 160-175 (p.165).

${ }^{41}$ Nicola Wilson, Home in British Working-Class Fiction (London: Ashgate, 2015), p.89; Ken Worpole, Dockers and Detectives: Popular Reading, Popular Writing (London: Verso, 1983). It is of course significant that the assertion is reiterated more than three decades later.

${ }^{42}$ Maguire, 'The State We're in', p.169.

${ }^{43}$ Heather Laird, 'Writing Working-Class Irish Women, in Pierse (2017), pp.122-139 (p.139).

${ }^{44}$ See Eamon Jordan, 'Multiple Class Consciousnesses in Writings for Theatre during the Celtic Tiger Era', Pierse (2017), pp.378-396. Also, see Michael Pierse, 'The People: Race and Class on the Contemporary Irish Stage', in Paige Reynolds (ed.), The New Irish Studies: Twenty-First Century Critical Revisions (Cambridge: Cambridge University Press, 2020).

${ }^{45}$ Ruth Sherry, 'The Irish Working Class in Fiction', in The British Working-Class Novel in the Twentieth Century, ed. by Jeremy Hawthorn (London: Edward Arnold, 1984), pp.111-123 (p.111).

${ }^{46}$ Though see for example Mary M. McGlynn, Narratives of Class in New Irish and Scottish Literature (New York: Palgrave Macmillan, 2008); Michael Pierse, Writing Ireland's Working Class: Dublin after O'Casey (London: Palgrave, 2009) and Aaron Kelly (ed.), The Irish Review (Special Issue: Culture and Class) 47 (December 2013).

${ }^{47}$ Fergal Finnegan and Barbara Merrill, "“We're as good as anybody else": a comparative study of workingclass university students' experiences in England and Ireland', British Journal of Sociology of Education 38.3 (2017), 307-324.

${ }^{48}$ Finnegan and Merrill, p.318.

${ }^{49}$ Roddy Doyle, The Woman Who Walked into Doors (London: Penguin, 1997), pp.25-26.

${ }^{50}$ See Pierse, Writing Ireland's Working Class, pp.26-30.

${ }^{51}$ bell hooks, 'Confronting Class in the Classroom', in The Critical Pedagogy Reader, ed. by Antonia Darder, Marta Baltodano, and Rodolfo D. Torres (New York: Routledge Falmer, 2003), pp.142-150 (p.142).

${ }^{52}$ Margaret Scanlon, Fred Powell, Pat Leahy, Hilary Jenkinson, and Olive Byrne, "“No one in our family ever went to college": Parents' orientations towards their children's post-secondary education and future occupations', International Journal of Educational Research 93 (2019), 13-22 (p.14).

${ }^{53}$ Elaine Keane, Manuela Heinz, and Andrea Lynch “"Working-class” student teachers: Not being encouraged at school and impact on motivation to become a teacher', Education Research and Perspectives 45 (2018), 7197 (p.72).

${ }^{54}$ Keane et al., p.75.

${ }^{55}$ Beverley Skeggs, 'Classifying Practices: Representations, Capitals and Recognitions' in Class Matters:

'Working-Class' Women's Perspectives on Social Class, ed. by Pat Mahony and Christine Zmroczek (London: Taylor \& Francis, 1997), pp.127-142 (p.127).

${ }^{56}$ Lucy O'Toole, 'Paul McVeigh launches The 32: An Anthology of Working Class Voices on crowdfunding publisher', Hot Press, 4 November 2019. Accessed online: https://www.hotpress.com/culture/paul-meveighlaunches-32-anthology-irish-working-class-voices-crowdfunding-publisher-22793381 [23 November 2019].

${ }^{57}$ Michelle M. Tokarczyk, introduction to Critical Approaches to American Working-Class Literature (New York: Routledge, 2014), p.5. 